ISSN: 1808-8759

\title{
FEASIBILITY OF SOLAR HEATING SYSTEMS COMPOSED OF RECYCLABLE PACKAGING FOR LOW-INCOME RURAL COMMUNITIES
}

\author{
Luís Roberto Almeida Gabriel Filho ${ }^{1}$, Tamara Maiochi ${ }^{2}$, Camila Pires Cremasco ${ }^{3}$, Danilo \\ Florentino Pereira ${ }^{4} \&$ Fernando Ferrari Putti $^{5}$
}

\begin{abstract}
Solar heaters are an appropriate technology in tropical and sub-tropical climates to heat bath water by solar energy. Low-cost solar heaters meet the demand of low-income rural communities which currently do not have access to this technology. Current research analyzes the economic viability of solar heaters, built with recyclable materials, to reduce electric energy bill. A solar heating system was built consisting of recyclable materials in accordance with the manuals provided by the Secretariat of Environment of the state of Paraná (SEMA). Duration of use of electric showers by families of rural properties was determined to calculate expenses and billing of electricity. Simulation and material costs showed that the system was feasible. Commercial solar heaters could be replaced at a cost of R\$22.61 per month during 13 months.
\end{abstract}

KEYWORDS: low-cost solar heaters, solar energy, electric power consumption.

\section{ANÁLISE DA VIABILIDADE ECONÔMICA DE SISTEMAS DE AQUECEDORES SOLARES COMPOSTOS POR EMBALAGENS RECICLÁVEIS PARA UTILIZAÇÃO EM COMUNIDADES RURAIS DE BAIXA RENDA}

RESUMO: Aquecedores solares constituem uma tecnologia adequada aos climas tropicais e sub tropicais para aquecer água do banho através da energia solar. Todavia, aquecedores solares de baixo custo buscam atender a demanda, principalmente comunidades rurais de baixa renda, que atualmente não possui acesso a esta tecnologia. O objetivo deste trabalho foi analisar a viabilidade econômica de aquecedores solares construídos com materiais recicláveis através da redução do faturamento de energia elétrica. Foi construído o sistema de aquecimento solar constituído de materiais recicláveis de acordo com os manuais disponibilizados pela Secretaria do Meio Ambiente do Paraná (SEMA), e considerados a contagem de tempo de utilização de chuveiros elétricos por famílias de propriedades rurais, a fim de se determinar os gastos e o faturamento de energia elétrica. Através dos gastos com materiais e de simulação, concluiu-se que o sistema mostrou-se viável, ao invés dos aquecedores solares comerciais, em que o investimento será pago em aproximadamente em 13 meses em parcelas de $\mathrm{R} \$ 22,61$.

PALAVRAS-CHAVE: aquecedores solares de baixo custo, energia solar, consumo de energia elétrica.

\footnotetext{
${ }^{1}$ UNESP - Univ Estadual Paulista, Campus Experimental de Tupã, Laboratório de Matemática Aplicada e Computacional; Faculdade de Ciências Agronômicas, Campus de Botucatu, Departamento de Engenharia Rural. E-mail: gabrielfilho@tupa.unesp.br

${ }^{2}$ UNESP - Univ Estadual Paulista, Campus Experimental de Tupã, Laboratório de Matemática Aplicada e Computacional. E-mail: tamaramaiochi@bol.com.br

${ }^{3}$ FATEC - Faculdade de Tecnologia, Campus de Presidente Prudente; Faculdade de Ciências Agronômicas, UNESP - Univ Estadual Paulista, Campus de Botucatu, Departamento de Engenharia Rural. Email: camila.gabriel@fatec.sp.gov.br
}

\footnotetext{
4 UNESP - Univ Estadual Paulista, Campus de Tupã. E-mail: danilo@tupa.unesp.br

5 UNESP - Univ Estadual Paulista, Faculdade de Ciências Agronômicas, Campus de Botucatu, Departamento de Engenharia Rural. E-mail: fernandoputti@fca.unesp.br
} 


\section{INTRODUCTION}

The employment of alternative energy source has currently been highlighted in the scientific community and in society. Due to possible scarcity of available natural and primitive resources in remote rural areas, without access to conventional electric energy, such alternatives as the use of solar energy are feasible and highly relevant solutions implying social, economical and environmental conditions have been proposed (BASSO et al., 2010; GABRIEL FILHO et al., 2012; 2010).

According to the Research Center for Electric Energy (1999), solar radiation may be absorbed by solar collectors, especially in the case of water heating, taking advantage of the thermal exploitation of solar energy. The technology is concentrated on the home, with collectors installed on the roof of houses and premises. A very good example is the conventional solar collector developed by Soletrol (2012).

In fact, conventional water heating systems are expensive and are not feasible for low income populations. Consequently, projects that decrease costs in the construction of solar water heaters are being developed, such as the 'Low-cost solar heater' project (ASBC) developed by the NGO Sun Society (SOCIEDADE DO SOL, 2012), at the Incubator Center of Technological Enterprises (CIETEC) of the University of São Paulo (USP/IPEN (Figure 1). The heater has a water heating system that captures solar energy in thermal-solar panels built from more low-cost materials such as spare parts and PVC tubes (PENEREIRO, 2010).

Another project, namely 'Energy for the Future', built by José Alcino Alano, a retired worker from Tubarão SC Brazil, installs solar heaters with recycled materials such as PET bottles and milk boxes. The project won the Super Ecologia 2004 prize, category NGO, promoted by the magazine Super-Interessante (DAMASIO \& STEFFANI, 2007).

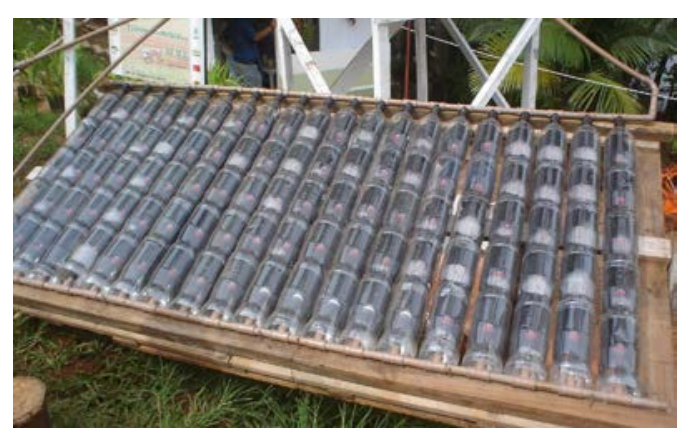

Figure 1: Solar heater built with PET bottles and Tetra Pak milk boxes (PARANÁ, 2008).

The feasibility and electric energy saving by replacing electric showers for solar heaters and the decrease of monthly energy costs have been proved since, according to Oliveira et al. (2008), irradiance or time during which the sun shines represent $55.2 \%$ of total daylight. The above is coupled to a return in the average costs after a little more than one year, according to the potency employed. In any case, the replacement of electric showers by solar heating systems is an asset for the latter mode.

The commercialization of solar heaters is currently very low. Many firms commercialize solar heater and NGOs exist with programs for the recycling of materials for their construction, although the government fails to support such initiatives through subsidies and application of the projects (SCHEIDT et al., 2010).

Solar heaters are being used worldwide since they present several environmental and economical advantages (HAKAN et al. 2013; TSILINGIRIS, 1996). In the wake of environmental issues, low cost solar heaters made of recycled materials for low-income communities (LINO et al. 2010) and used in rural homes (CHATURVEDI, et al. 2014) are greatly welcomed.

However, studies on the economical feasibility lack certain methods for the undertaking, featuring interest rates, electric energy consumption per capita, costs of material used, and comparisons with costs of electric energy heating (GABRIEL FILHO, 2008).

In the case of low income communities, low cost water heaters may be a feasible unique solution in places where rural electricity is still not extant (GABRIEL FILHO, et al. 2011).

Current analysis evaluates the economical viability of solar heating system made of recyclable material and compares its implantation costs with those of conventional commercial solar heaters and the use of electric shower heads.

\section{MATERIALS AND METHODS}

The materials used for the construction of solar heaters are listed in the handbook available from the Secretary of the Environment and Water Resources of the state of Paraná (SEMA, 2011). Prices of the materials were collected in the municipality of Tupã SP Brazil.

The calculation of energy costs and electric energy bills for shower heads was highly relevant for the economical feasibility of the solar heating system through the determination of pay-off and returns of the initial investment (ALTOÉ et al. 2012).

\subsection{Description of the proposed solar heating system}

The thermosiphon is the working principle that better adapts itself to simple systems such as the proposed solar heater. The installation of the collector should have a higher bar (2), linked to hot water, that would be connected to the reservoir (water tank), whereas the lower bar (1), linked to cold water, would be connected 
to the lower section (Figure 3).

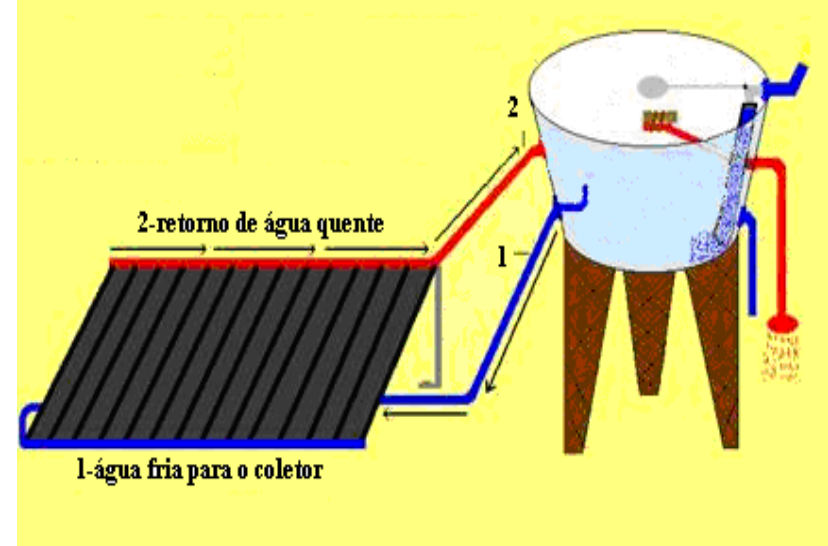

Figure 3: The thermosiphon process of a water heating system (adapted from SEMA, 2011).

Difference in height warrants the circulation of water, caused by the difference of the hot water's density to that of cold water. As water becomes hot in the collector's column, it rises to the reservoir's upper part due to the cold water pressure which, being heavier, flows towards the collector's lower section by pushing the hot water towards the upper section of the water tank.

The solar collector of the heater is composed of tubes, PVC connections, PET bottles and Tetra Pak milk boxes (Figure 4) which replace the conventional copper or aluminum tubes, the metal box, the thermal absorption panel and glass used in conventional collectors.
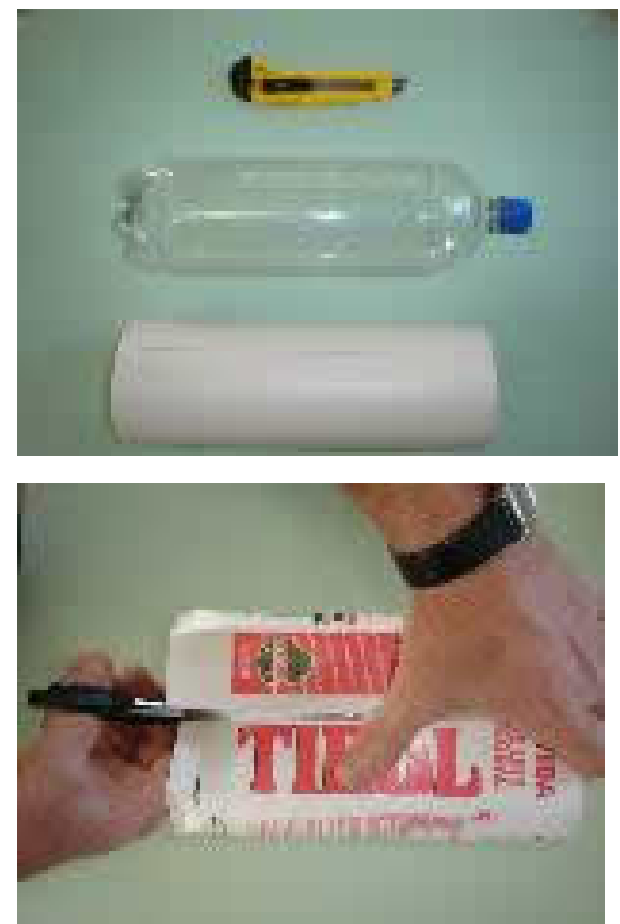

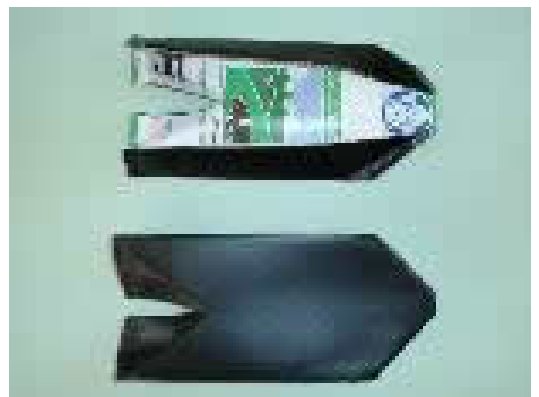

Figure 4: Cutting of bottles and milk boxes for the construction of the solar panel.

The construction of the solar collector is characterized by the locking of PET bottles and milk boxes with a better absorption of the solar energy received. Figure 5 displays a set of tubes, joints, bottles and milk boxes that make up the collector, coupled to a cross-section of the collector. The heater functions through the thermosiphon process, according to display on Figure 6.

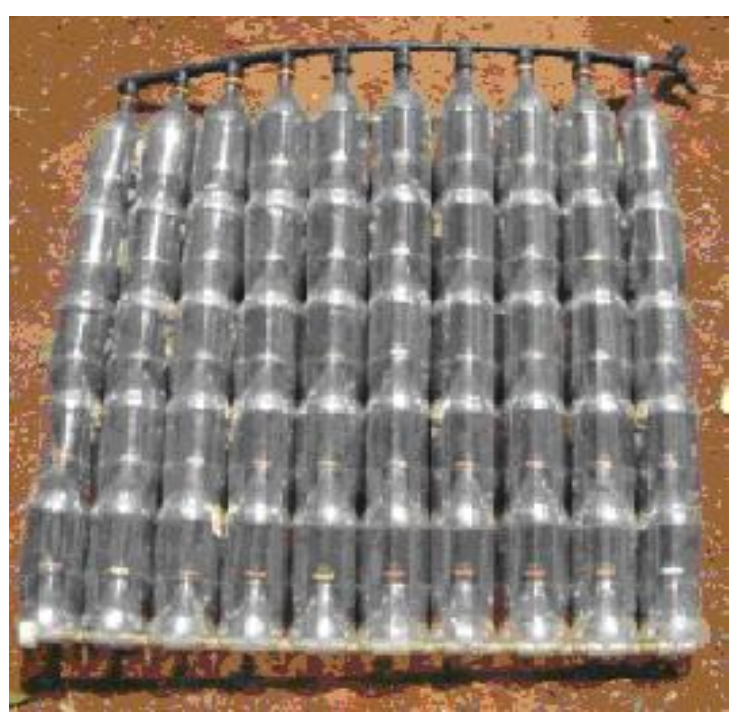

Figure 5: Solar collector

Source: SEMA (2011).

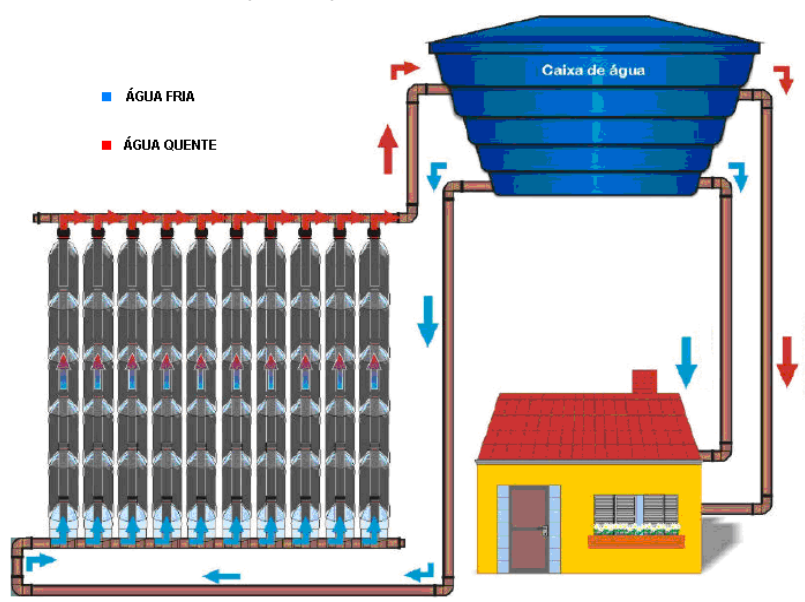

Figure 6: Running the solar heater.

Source: SEMA (2011). Fonte: SEMA (2011). 


\subsection{Costs of the material employed in the solar heater proposed}

The construction of the solar heater requires a list of products found in the SEMA handbook (2011). Estimates given by building material shops in Tupã SP Brazil were undertaken so that costs of the required material, listed in Table 1, for the construction of the system could be calculated

Table 1: Estimates of materials for the building of a solar heater for the use of a four-person family.

\begin{tabular}{cccc}
\hline \multicolumn{4}{c}{ Estimates - Solar heater - 4 persons } \\
\hline Product & Quantity & $\begin{array}{c}\text { Unit } \\
\text { price } \\
\text { (R\$) }\end{array}$ & $\begin{array}{c}\text { Total } \\
\text { price } \\
\text { (R\$) }\end{array}$ \\
\hline Coping saw & 1 & 11.00 & 11.00 \\
\hline Adhesive tape & 1 & 2.75 & 2.75 \\
\hline Self-fusion thread & 1 & 14.00 & 14.00 \\
\hline Rubber hammer & 1 & 6.50 & 6.50 \\
\hline A liter of paint & 1 & 12.00 & 12.00 \\
\hline 5 cm roll & 1 & 3.25 & 3.25 \\
\hline Abrasive paper & 1 & 0.50 & 0.50 \\
\hline Glue & 1 & 6.25 & 6.25 \\
\hline 20 mm 1 ? PVC tube & 58 & 1.50 & 87.00 \\
\hline T joint & 81 & 0.50 & 40.50 \\
\hline L-connection & 13 & 0.25 & 3.25 \\
\hline Lid & 8 & 0.50 & 4.00 \\
\hline 100 mm PVC tube & 1 & 6.75 & 6.75 \\
\hline 50 mm PVC tube & 0.5 & 4.50 & 2.25 \\
\hline 40 mm drain pipe & 8 & 2.50 & 20.00 \\
\hline Mixer & 1 & 78.00 & 78.00 \\
\hline Total & & & $\mathbf{2 9 8 . 0 0}$ \\
\hline Source: mad by the & & & \\
\hline
\end{tabular}

Source: made by the authors.

\subsection{Methodology employed}

Methodology comprised an analysis of energy cost of electric shower heads and the economical viability of the solar heater proposed in current study. Economical feasibility determined the monthly costs in employing a system exclusively made up of electric shower heads. Quantitative methods related to financial mathematics estimated the time required for the paying off of initial investment to build the proposed solar heater.

The following equation for the calculation of energy used in a constant potency engine was employed:

$$
E=P . T
$$

where:

$E$ - spent energy, Wh;

$P$ - potency of the apparatus used (electric shower head), W (Watt);

$T$ - usage time of the electric shower, h (hour).

The following constants had to be defined so that energy costs for monthly baths with electric showers could be calculated:

$t$ - bath duration, h (hour);

$$
\begin{aligned}
& n \text { - number of persons; } \\
& m \text { - number of days of the month; } \\
& G \text { - monthly costs of electric shower, R\$; } \\
& u \text { - price per kWh, R\$. }
\end{aligned}
$$

According to Assaf Neto (2009), interest on the outstanding balance are decreasing rates, whilst paying-off installments have rising rates. Interests decrease and pay-off increases during time duration with the sum of the two parts remaining equal to installment.

The system developed consists of fixed installments up to the penultimate month of pay-off, with the lowest installment on the last month. In fact, Installment Rate will be calculated through a calculation of current electric energy cost with electric shower heads.

Expressions for calculating the pay-off system are given as pay-off, installment, outstanding balance and interests produced by the outstanding balance. Pay-off (Amort) for time $t$ is obtained by the difference between the installment rate (PMT) and the interest rate $(\mathrm{J})$ :

$$
\text { Amort }_{t}=P M T-J_{t}
$$

Outstanding balance ( $S D$ ) for each period is obtained by the difference between the debt at the start of the time interval and the pay-off during the period. Consequently, outstanding balance of $t$ for a given interest rate is obtained by.

$S D_{t}=S D_{t-1}-$ Amort $_{t}$

Interest rate $(J)$ on the outstanding balance calculated at the start of the period $t$ (or at the end of the immediate former period) with regard to interest rates $i$ is given by:

$J_{t}=S D_{t-1} \cdot i$ 


\section{RESULTS AND DISCUSSION}

\subsection{Theoretical results}

According to IBGE (2013), the ideal family is a fourperson family, with each person taking a 10-minute bath per day. Time for monthly bath $T$ in a home with $n$ people is given by:

$T=n \cdot t \cdot m$

Energy $E$ used monthly for electric showers baths is given by:

$$
E=P . T \Rightarrow E=P . n . t . m
$$

When one takes into account that the average power of each electric shower head is 5400 watts and calculating a family composed of four persons using the electric shower during 10 minutes per day $(10 / 60 \mathrm{~h})$ during 30 days, the monthly costs in energy are:

$$
E=\text { P.n.t. } m=5400.4 .\left(\frac{10}{60}\right) \cdot 30=108000 \mathrm{Wh} \Rightarrow E=108 \mathrm{kWh}
$$

The Vale do Paranapanema Electricity Holding, the distributor of electric power for the town of Tupã and its neighborhood, has a total cost (rates + taxes) of R\$ 0.29910 per kWh (ANEEL, 2013), with u $=0.29910$. Monthly energy costs is determined by the formula:

$$
G=E . u=108.0 .29910 \Rightarrow G=32.30
$$

Consequently, the monthly costs of a four-person family using the electric shower amount to R\$33.99. Table 2 will be employed to determine the heater's investment return, demonstrating the pay off of investment for the installation of the proposed system. However, the values of each installment and other parameters should be known beforehand.

In spite of the installation of the solar heater, the complementary use of electrical heating at the rate of $30 \%$ of former costs was required. The above average is due to the fact that the electric system plus the solar heater will be more intensely employed on cloudy days or in days with very low temperatures.

It has been verified that water heating by the electric system has to be used on 3 days in every 10 days. Therefore, the $70 \%$ saving (100\% - 30\%) would be equivalent to an installment for paying off the initial investment:

$$
P=70 \% G=0.70 .32 .30=22.61
$$

Interest rates on initial capital (investment on the heating system) were $0.6 \%$ rates of the current saving account and the lowest in commercial transactions. Table 2 shows the months following investment with outstanding balance, pay-off, interests and installments. Installments were first calculated, followed by interests for each period; interests were determined and, through the difference, installments for pay-off and the respective outstanding balance. Calculations are given for the first month:

$$
\begin{aligned}
& J_{1}=S D_{0} . i=300.0 .006=1.80 \\
& \text { Amort }_{1}=P M T-J_{1}=22.61-1.80=20.81 ; \\
& S D_{1}=S D_{0}-\text { Amort }_{1}=300-22.61=277.39
\end{aligned}
$$

Table 2: Results for the pay-off method on the investment for solar heaters.

\begin{tabular}{ccccc}
\hline $\begin{array}{c}\text { Period } \\
\text { (months } \\
\text { ) }\end{array}$ & $\begin{array}{c}\text { Outstanding } \\
\text { balance } \\
\text { (R\$) }\end{array}$ & $\begin{array}{c}\text { Pay- } \\
\text { off } \\
\mathbf{( R \$ )}\end{array}$ & $\begin{array}{c}\text { Interests } \\
\mathbf{( R \mathbf { } )}\end{array}$ & $\begin{array}{c}\text { Installment } \\
\mathbf{( R \mathbf { } )}\end{array}$ \\
\hline 0 & 300 & - & - & - \\
\hline 1 & 279.19 & 20.81 & 1.80 & 22.61 \\
\hline 2 & 258.26 & 20.93 & 1.68 & 22.61 \\
\hline 3 & 237.19 & 21.06 & 1.55 & 22.61 \\
\hline 4 & 216.01 & 21.19 & 1.42 & 22.61 \\
\hline 5 & 194.69 & 21.31 & 1.30 & 22.61 \\
\hline 6 & 173.25 & 21.44 & 1.17 & 22.61 \\
\hline 7 & 151.68 & 21.57 & 1.04 & 22.61 \\
\hline 8 & 129.98 & 21.70 & 0.91 & 22.61 \\
\hline 9 & 108.15 & 21.83 & 0.78 & 22.61 \\
\hline 10 & 86.19 & 21.96 & 0.65 & 22.61 \\
\hline 11 & 64.10 & 22.09 & 0.52 & 22.61 \\
\hline 12 & 41.87 & 22.23 & 0.38 & 22.61 \\
\hline 13 & 19.51 & 22.36 & 0.25 & 22.61 \\
\hline
\end{tabular}

Source: prepared by the authors.

Pay-off time for the proposed system will be paid by the client in 13 fixed installments at $\mathrm{R} \$ 22.61$ each; an installment of R\$2.85 is due on the 14th month.

\section{CONCLUSIONS}

Economical feasibility of the solar heating system prepared from recycled material warranted the viability of the equipment, with a pay-off of approximately 13 months, at fixed installments of $\mathrm{R} \$ 22.61$ and equivalent to $70 \%$ of the rates paid for the conventional electric system formerly used for water heating.

Current analysis was foregrounded on a four-person family, each taking a daily 10-min bath. If analysis of feasibility takes into account an average bath-taking 
period over 10 minutes, pay-off time will be less. In other words, the highest the consumption of electric energy with electric showers, the less will be the pay-off time for the investment proposed in current research.

\section{ACKNOWLEDGEMENTS}

The authors would like to thank the Conselho Nacional de Desenvolvimento Científico e Tecnológico (CNPq) for funding the research (Process 480985/2008-1).

\section{REFERENCES}

AGÊNCIA NACIONAL DE ENERGIA ELÉTRICA. Energia Solar. Brasilia-DF, 2005. Available at: < http://www.aneel.gov.br/aplicacoes/atlas/download.htm $>$. on 2 September 2013.

\section{ASSAF NETO, A. Matemática financeira e suas} aplicações. 11. ed. São Paulo: Atlas, 2009.

ALTOÉ, L.; OLIVEIRA FILHO, D.; CARLO, J. C. Energy analysis of solar thermal systems for different demands of hot water in a single family dwelling. Ambiente Construído, Viçosa -MG, v. 12, n. 3, p. 75-87, 2012.

BASSO, L. H.; SOUZA, S. N. M.; SIQUEIRA, J. A. C.; NOGUEIRA, C. E. C.; SANTOS, R. F. Análise de um sistema de aquecimento de água para residências rurais, utilizando energia solar. Engenharia Agrícola, Jaboticabal, v. 30, n. 1, p. 14-21, 2010.

CENTRO DE PESQUISAS DE ENERGIA ELÉTRICA. Centro de Referência para Energia Solar e Eólica Sérgio de Salvo Brito. Manual de engenharia para sistemas fotovoltaicos. Rio de Janeiro, 1999. 204 p.

CHATURVEDI, S.K.; GAGRANI, V.D.; ABDELSALAM, T.M. Solar-assisted heat pump - A sustainable system for low-temperature water heating application. Energy Conversion and Management. v.77, p. 550 $557,2014$.

DAMASIO, F.; STEFFANI, M. H. Ensinando física com consciência ecológica e com materiais descartáveis. Revista Brasileira de Ensino de Física, São Paulo, v. 29, n. 4, p.593-597, 2007.

GABRIEL FILHO, L. R. A. CREMASCO, C. P; SERAPHIM, O. J; CANEPPELE, F. L. Caracterização analítica e geométrica da metodologia geral de determinação de distribuições de Weibull para o regime eólico e suas aplicações. Engenharia Agrícola, Jaboticabal, v. 31, n. 1, p.55-66, 2011.

GABRIEL FILHO, L. R. A.; CREMASCO, C. P.; SERAPHIM, O. J. Análise diferencial da potência máxima gerada por um sistema solar fotovoltaico.
Energia na Agricultura, Botucatu, v. 25, n. 2, p.123$138,2010$.

GABRIEL FILHO, L. R. A. CREMASCO, C. P. ; MAIOCHI, T. ; PEREIRA, D. F. ; MAGALHÃES, M. M. . Análise da viabilidade econômica de sistemas de aquecedores solares compostos por embalagens recicláveis para utilização em comunidades rurais de baixa renda In: Congresso Brasileiro de Engenharia Agrícola - CONBEA, 40., 2011, Cuiabá. Geração de tecnologias inovadoras e o desenvolvimento do cerrado brasileiro. Jaboticabal: SBEA, 2011. p.1-10.

GABRIEL FILHO, L. R. A., SERAPHIM, O. J., CREMASCO, C. P., CANEPPELE, F. L.

Metodologia da determinação dos parâmetros característicos de sistemas eólicos de geração de energia. Revista Technologia, Canoas , v.9, p.15 - 27, 2008.

GABRIEL FILHO, L. R. A.; VIAIS NETO D.S.; CREMASCO, C. P.; SERAPHIM, O. J CANEPPELE, F. L.. Mathematical analysis of power generated by photovoltaic systems and their applications in rural areas. Engenharia Agrícola, Jaboticabal, v. 32, n. 4, p.650-662 , 2012.

IBGE. Pesquisa nacional de saneamento básico. Rio de Janeiro, 2013.

OLIVEIRA, L. F. C. FERREIRA,R.C.;ALMEIDAR.A.;LOBATO,E.J. V.; MEDEIROS, A. M. DE M.. Potencial de redução do consumo de energia elétrica pela utilização de aquecedores solares no estado de Goiás. Engenharia Agrícola, Jaboticabal, v. 28, n.3, p. 406-416, 2008.

OZTOP, H.F.; BAYRAK, F.; HEPBASLI, A.; Energetic and energetic aspects of solar air heating (solar collector) systems. Renewable and Sustainable Energy Reviews. v.21, p.59-83, 2013.

LINO, F.A.M.; BIZZO, W.A.; SILVA, W.A.; ISMAIL, K.A.R. Energy impact of waste recyclable in a Brazilian metropolitan. Resources, Conservation and Recycling. v.54, n. 11, p.916-922, 2010.

PENEREIRO, J. C.; MELO, L. P.; CORADI, T. B. Construção de um aquecedor solar de baixo custo sem cobertura: análise experimental da eficiência térmica para vários ensaios. Revista de Ciência \& Tecnologia, v. 10, n. 1, p. 18-34, 2010.

PARANÁ (Estado). Secretaria do Meio Ambiente e Recursos Hídricos. Aquecedor solar construído com materiais recicláveis. Curitiba, 2008. Available at: $<$ http://www.meioambiente.pr.gov.br/arquivos/File/meio ambiente/solar.pdf>. on $1^{\text {st }}$ September 2012. 
SCHEIDT, F. S. S.; SILVA, P. R. D., SILVA, S. M. C. P. D., \& HIROTA, E. H. . Consideração de requisitos ambientais em empreendimentos habitacionais de interesse social: um estudo de caso. Ambiente Construído, v. 10, n. 1, p. 53-68, 2010.

SOCIEDADE DO SOL. Manual de instrução e montagem experimental do ASBC . São Paulo, 2009. Available at: $<$ www.sociedadedosol.org.br $>$. on 1st September 2012.

SOLETROL. Aquecedores solares de água. Available at: <http://www.soletrol.com.br>. on 1st September 2012.

TSILINGIRIS, P.T. Design and performance of large low-cost solar water heating systems. Renewable Energy. v.9, p. 617-621, 1996. 